Croatian International Relations Review - CIRR

XXIII (80) 2017, 13 1-754

ISSN 1848-5782

UDC 355/359:342.7/497. 1171

DOI 10.1515/cirr-2017-0023

\title{
International Security Presence in Kosovo and its Human Rights Implications
}

Remzije Istrefi

\section{Abstract}

In this article I will examine the powers and activities of NATO-led Kosovo forces (KFOR) and their impact on human rights protection in Kosovo. Through this examination, I seek to answer the following questions: which KFOR actions affected the human rights of Kosovars? Does KFOR carry out responsibilities and abide by the obligations normally imposed upon nation-states? And is there a solution available when the alleged violator is KFOR? KFOR is responsible for carrying out military tasks and for 'shouldering' UNMIK and local security forces in some civilian peace-building tasks. In the course of the exercise of its mandate, there were alleged complaints of human rights violations by KFOR. The legal implications of these alleged complaints against KFOR (in)actions will also be discussed.

KEY WORDS:

Kosovo forces, KFOR, human rights, accountability, security, NATO, UNMIK 
In June 1999, after a 78-day NATO military campaign over Yugoslavia, the United Nations established the United Nations Mission in Kosovo (UNMIK). Under the vast authorities of the Special Representative of the Secretary General (SRSG), UNMIK remains unprecedented in both its scope and its structural complexity (Murphy 2005: 9). Unlike many other previous UN missions, UNMIK was formally divided into civilian and military components. The international civil component was mandated "to provide an interim administration for Kosovo under which the people of Kosovo could enjoy substantial autonomy" (United Nations Security Council Resolution 1244 1999: 10). The NATO-led Kosovo security forces, known as KFOR, were responsible for "carrying out military tasks" and "shouldering" UNMIK in civilian peace-building tasks (United Nations Security Council Resolution 1244 1999: 9). Initially, the establishment of an international security force in Kosovo was discussed during the NATO air campaign over the Federal Republic of Yugoslavia (FRY) by the G8 foreign ministers (CNN 1999; Youngs et al. 1999: 61). Its establishment was legalized through adoption of the so-called peace plan by the FRY authorities on 3 June 1999 (United Nations Security Council Peace Plan 1999). The peace plan provided for the establishment of an "international security force under UN auspices with substantial NATO participation under unified command and control" (United Nations Security Council Peace Plan 1999: 3-4). The peace plan was reaffirmed in the Military Technical Agreement (MTA) concluded between the FRY and the International Security Force on 9 June 1999 (Military Technical Agreement 1999).

The scope of KFOR authorities included "the authority to take all necessary action to establish and maintain a secure environment for all citizens of Kosovo and otherwise carry out its mission" (Military Technical Agreement 1999: sec. 2). The KFOR mission and its broad authority were vested in the Commander of the International Security Force (COMCFOR). COMCFOR had the authority "without interference or permission to do all that he judges necessary and proper including the use of military force, to protect the international security force, the international civil presence and to carry out the responsibilities as provided in MTA" (Military Technical Agreement 1999: Appendix B). Even though the MTA provided that "the parties to the 
agreement will agree on a Status of Forces Agreement (SOFA) through a bilateral agreement" (Military Technical Agreement 1999: Appendix B, sec. 3), the legal status of KFOR was regulated unilaterally. KFOR did not negotiate with the FRY on a SOFA because it wanted "politically to isolate the Belgrade regime" and "it did not want to conclude international agreements with the FRY which if concluded would have inhibited the competence of the UN-led civil mission" (Zwanenburg 2005: 46). Instead, the principles under which KFOR would function (i.e. its rights and duties) were regulated by the Interim Status of Forces Policy promulgated by the Commander of KFOR in 1999, which was replaced by a common declaration by KFOR and UNMIK and promulgated as UNMIK Regulation 2000/47. In essence, UNMIK Regulation 2000/47 substituted a SOFA as the necessary legal instrument to provide special freedoms, privileges and duties and enable KFOR to carry out its mandate. Although UN SCR 1244 made the civilian and military components equal partners (United Nations Security Council Resolution 1244 1999: 17), KFOR was not subject to oversight by the UN Secretary General or his Special Representative (SRSG) in Kosovo. MTA provided that KFOR would "deploy and operate without hindrance within Kosovo and with the authority to take all necessary action to establish and maintain a secure environment for all citizens of Kosovo including arrest and detention of persons who might interfere with mission accomplishments" (Military Technical Agreement 1999: Annex B. 1). This KFOR mandate, combined with broad authorities vested in its Commander, the specific measures taken on the ground and KFOR's lack of liability, is in contravention of international human rights standards. With the declaration of Kosovo's independence on 17 February 2008, UNMIK authorities were reconfigured (United Nations Security Council Secretary General's Report on the United Nations' Interim Administration Mission in Kosovo 2008). KFOR was still mandated with securing peace and security in Kosovo under UNSC Resolution 1244. Since June 2008, NATO has implemented additional tasks in Kosovo: it has assisted in the standing down of the Kosovo Protection Corps (KPC), and supported the establishment of the Kosovo Security Forces (KSF) and the civilian structure to oversee the KSF.

Despite the changes to the political status of Kosovo, KFOR actions that have affected human rights still remain a debated issue. In the following sections, I will analyse KFOR command and control as a structural matter 
and its impact on KFOR performance in realizing its mandate as provided in UN SCR 1244. Then I will discuss certain actions undertaken by KFOR in accordance with its mandate and their human rights implications. The issue of attribution of wrongful conduct as it is defined by the International Law Commission (ILC) and application of international human rights standards to KFOR based on the concept of extraterritoriality will be analysed in order to identify a possible mechanism with jurisdiction over KFOR member states. Finally, I will discuss the reasoning of the European Court of Human Rights on two applications brought by Kosovars against the nation states of troop contributing forces, Behrami v. France and Saramati v. France, Germany and Norway, and examine how all the mentioned issues have been considered by the Court. The paper will conclude with a recommendation for the necessity to establish a mechanism for remedying the human rights violations resulting from KFOR (in)actions.

\section{Command and control of KFOR}

Although UN SC Resolution 1244 was the legal base for its establishment, KFOR was not subject to the UN Secretary General or to UNMIK Special Representative of Secretary General (SRSG). The cooperation between UNMIK and KFOR on the ground is very interrelated, but never reflected on the issue of command and control, UNMIK apparently "coordinates" with but does not control KFOR (Amnesty International 2004a: 9). The first SRSG Bernard Kouchner presented the "relationship as the head of the UNMIK administration and the KFOR commander as being twin brothers" (Kouchner 2001). KFOR specific command and control was described as a state that "does not amount to the required democratic control over the armed forces" and there were calls for UN SCR 1244 "to be interpreted in conformity with the essential requirement of democracy according to which the military is subject to civilian control" (Council of Europe 2002: 21). Traditionally, command is defined as "the legal authority to issue orders and to compel to obedience" (Eccles 1965: 118-119). Control is "the process through which a commander, assisted by staff, organizes, directs and co-ordinates activities of the assigned force in a given territory" (Murphy 2005: 121). In operational 
terms, command and control processes provide for "organization and management of daily operations to implement the given mandate" (Murphy 2005: 121-22). In the case of KFOR, daily operations would be activities for ensuring public safety and, with it, protection of human rights as assigned to by UN SCR 1244. KFOR forces operated under the KFOR Commander, who was appointed by NATO through a "unified control and command" (United Nations Department of Peacekeeping Operations 2008: Chapter 7). The "unified control and command" is in line with all other UN authorized peacekeeping forces that have different components - civil, military and police - and that comprise different military contingents provided by the troop-contributing states (ibid.). KFOR forces were to be "responsible to the Commander-in-Chief of the Allied Forces, Southern Europe" (CINCSOUTH) (Zwanenburg 2005). On the ground, "the multinational command did not extend to the administrative control over contingents or to personnel management" (European Commission for Democracy through Law 2004). The administrative control was instead "regulated with the national laws and policies of each contingent, which differed widely from one state to the other" (Murphy 2007: 158-173). This actual control is known as the "red card procedure", giving the contingents "the right not to take orders if such orders would contradict their national policy" (Cerone 2001: 486) or, as is the case with some forces (i.e. Canadian forces), where the national command cannot be handed over to a foreign commander at any time (Murphy 2005: 106-107). In the case of KFOR operations, this form of command posed challenges, as KFOR was composed of military contingents contributed by 35 NATO members and non-NATO members (European Commission for Democracy through Law 2004: 5). On the ground, this meant that each contingent in the course of exercising their daily operations applied its own rules of engagement (ROE) and standard operating procedures (SOP) (Spillmann et. al. 2001: 148). During waves of ethnic violence in Kosovo, "KFOR response to crowd and riot control operations was thus chaotic and the protection of the minority communities was catastrophic" (International Crisis Group 2004). In general, crowd and riot control operations aim to suppress outbreaks of violence, in particular ethnically and religiously motivated violence, and thus ultimately aim to prevent upheavals from crossing the threshold into internal armed conflict. These operations play a particular role in the protection of designated people and the defence of property with designated special status (PDSS). In Kosovo, the designated people 
referred to minority communities like the Albanians or Serbs in a given area, and PDSS referred to their property and their cultural heritage. It has been stated that several times "KFOR failed to respond to the security problems in Kosovo and with it failed to protect minorities because of the lack of a unified command for all KFOR sectors in implementing KFOR unified policy on responding to public order situations" (Human Rights Watch 2004).

\section{KFOR activities in Kosovo and human rights implications}

In the first years of administration, UNMIK and KFOR were faced with a volatile security situation that required a quick response. KFOR had to undertake policing activities over the entire territory of Kosovo until the international civilian police established capacities to take on full responsibilities. On the ground, KFOR had not only the role of civilian police, arresting and detaining ex-and would-be belligerents suspected of committing war crimes, murder, attempted murder, rape, weapon offences and other serious crimes, but also conducted so-called operational detentions, ran local prisons, controlled traffic and assisted refugees in Kosovo. KFOR had to engage daily in riot control operations in order to keep hostile ethnic groups from clashing violently. KFOR still continued to shoulder the Kosovo Police Service (KPS) during interethnic unrests, particularly in the ethnically divided town of Mitrovica. While carrying out its duties, KFOR was criticized for failure to ensure security for minorities, failure to secure peaceful enjoyment of property, arbitrary arrests and unlawful detention, ill treatment of detainees, denial of detainee rights and lack of KFOR accountability (Amnesty International 2000; Human Rights Watch 2004; International Crises Group 2004). It is beyond the scope of this article to analyse in detail all the mentioned allegations. The following section will discuss the so-called COMCFOR detentions and their effects on the individual's rights. 


\section{COMKFOR detentions}

International organizations and advisory bodies (European Commission for Democracy through Law 2004; Organization for Security and Cooperation in Europe 2002), international NGOs (Amnesty International 2004a, Amnesty International 2004b, Human Rights Watch 2004) and scholars (Cerone 2000; Marshall and Inglis 2003; De Wet 2004; Zwanenburg 2005; Direk 2015) have discussed the legality and human rights implications of KFOR detentions under KFOR command. These detentions were based on Detention Directive 42, which allowed "the head of KFOR to authorize detentions for long periods without judicial authorization or any recourse to judicial review" (European Parliament DG Information 2001). In 2002, the Organization for Security and Cooperation in Europe mission in Kosovo (OMIK) reported "On the basis of information received from KFOR that an average of 10 persons each month were held under the Multinational Brigade Commander's authority, based on Directive 42" (Organization for Security and Cooperation in Europe 2002). The detainees under Directive 42 involved "criminal offenders; individuals that pose threat to peace and security; persons suspected for different offences; and persons under judicial detention" (Organization for Security and Cooperation in Europe 2002; Joseph 2003; Marshall and Inglis 2003: 15). The main human rights implications of COMCFOR detentions by order of the KFOR Commander involve the exercise of authority without judicial review and adverse effects on the right of access to court. COMCFOR detentions also affected the liberty of the person and freedom of movement. OSCE, as the UNMIK human rights component, and international human rights groups have heavily criticized COMKFOR detentions for "being in contravention of international laws and the applicable law in Kosovo" (Organization for Security and Cooperation in Europe 2002; United Nations Human Rights Committee 2004). "These detentions are being carried out by military forces and are not based on a decision by a competent judiciary, and they do not allow for judicial or any civilian oversight" (Organization for Security and Cooperation in Europe 2002; United Nations Human Rights Committee 2004). Moreover, there was no possibility for detainees to challenge the legality of their detention (UNMIK Reg. 2000/47 2000). Promotion and protection of human rights was one of the main tasks of UNMIK (United Nations Security Council Resolution 1244 1999: sec.j). 
UNMIK Regulation 1999/24, amended by UNMIK Regulation 2000/59, on the applicable law in Kosovo guaranteed the application of major human rights treaties, including "....human rights standards contained in the Universal Declaration on Human Rights [...], European Convention on Human Rights [...], the International Covenant on Civil and Political Rights [...], the International Covenant on Economic, Social and Cultural Rights $[\ldots]$, the Convention on the Elimination of All Forms of Racial Discrimination $[\ldots]$, the Convention on Elimination of All Forms of Discrimination Against Women [...], the Convention Against Torture and Other Cruel, Inhumane or Degrading Treatment or Punishment [ ] and the International Convention on the Rights of the Child" (UNMIK Reg. 2000/59 2000: sec.1). Section 3(5) of UNMIK Regulation 2000/47 obliged "UNMIK personnel to respect the laws of Kosovo and to refrain from any action incompatible with the applicable laws" (UNMIK/Reg. 2000/47 2000).

Scholars infer that KFOR was bound to respect the applicable law of Kosovo while exercising law enforcement activities, since this obligation stems from the Charter itself and binds UN organizations when undertaking the civil administration of a territory regardless of a resolution or regulation to this effect (Cerone 2000; Marshall and Inglis 2003; De Wet 2004; Benedek 2005; Zwanenburg 2005; Direk 2015). In addition, it has been argued that human rights obligations apply to KFOR (and UNMIK) based on territorial control of KFOR-contributing states over the beneficiaries of rights (Cerone 2001: 418). The relevant NATO operation plans (OPLANs), directives, and standing operating procedures (SOPs) for the peacekeeping forces in the Balkans required "compliance either explicitly or implicitly with the spirit of International Humanitarian Law (IHL) and respect for Human Rights Law $(\mathrm{HRL})$ in the course of the operations they govern" (European Commission for Democracy through Law 2004). Also, the authorization granted to KFOR in Resolution 1244 to participate in the civil administration implies that the countries acting on behalf of the SC would act in accordance with human rights norms (United Nations Security Council Report Secretary General's Report on the United Nations' Interim Administration Mission in Kosovo 1999; UNMIK Reg. 1999/24 1999: Art. 1). KFOR would therefore be required "to act in accordance with the basic human rights norms when engaged in policing and other civil activities, as opposed to military combat" (De Wet 2004: 321). However, UNMIK provided that "KFOR shall respect applicable law that provides for international human rights norms and UNMIK 
Regulations only insofar as they do not conflict with the fulfilment of the mandate given under SC Resolution 1244" (UNMIK Reg. 2000/47 2000: sec. 2, para. 2). Moreover, UNMIK Regulation $200 / 47$ granted immunity from jurisdiction to UNMIK and KFOR, and "thus from the very beginning there were no mechanisms to challenge KFOR's activities that were in breach of human rights standards in Kosovo" (De Wet 2004: 321).

\section{Attribution of KFOR actions to NATO, UNMIK or contributing states?}

There is a general acceptance of the stance that international organizations possess legal personality (International Court of Justice 1949). However, there is no common consensus on the legal personality of peacekeeping operations. In its commentary on the draft Article 13 concerning the responsibility for atrocities of international organizations, the International Law Commission (ILC) presented the KFOR and UNMIK relationship as an "example of two international organizations allegedly exercising direction and control in the commission of a wrongful act" (United Nations International Law Commission 2005: para. 27). The ILC further reinforced its presentation on KFOR by quoting the French Government's Preliminary Objections to the Legality of Use of Force, which submitted that "NATO is responsible for the direction of KFOR and the United Nations for "control' of it" (Serbia and Montenegro v. France 2004). However, the fact that UNMIK had no operational authority over KFOR is evident from UN SCR 1244, from UNMIK Regulation 2000/47, and from the assertions of NATO authorities. KFOR General Reinhardt stated categorically that "UNMIK has neither legal jurisdiction nor mandate to conduct investigations into KFOR activities"' (Amnesty International 2000). The UN authority over KFOR is limited only to the requirement of receiving and evaluating reports by "the leaderships of the international civil and security presences", as provided in UN SC Resolution 1244 (United Nations Security Council Resolution 1244 1999: para. 20). It has been submitted that international peacekeeping operations are not subjects of international law in their own right; rather, "they form part of the organizational framework of their lead organizations" (Clapham 2006: 148-151). From the consolidated United 
Nations practice, UN peacekeeping operations are subsidiary organs to the organization. Although NATO has not made an express statement of a similar nature, by the fact that NATO de facto integrated respective force headquarters into its headquarters structure, it is acceptable to assume that NATO peacekeeping operations have been considered subsidiary organs of NATO. On this basis, the conduct of KFOR could be attributed to NATO as the leading organization. However, the issue of attribution of wrongful conduct has not been explicitly clarified in the legal documents establishing KFOR and UNMIK. Therefore, for quite a long time the issue of jurisdiction over the wrongful acts committed by KFOR troops has remained in interplay between the attribution of conduct to NATO as the lead organization and the jurisdiction of the troop-contributing state contingents of KFOR. The issue of attribution of acts to UNMIK and KFOR was interpreted only in 2007 by the European Court in two cases brought by Kosovo citizens, to be discussed in the sections below.

\section{The principle of extraterritorial application of international human rights and its applicability to KFOR}

Scholars and practitioners have presented different modalities of the application of human rights and humanitarian law to KFOR. The most supportive modality remains the extraterritorial application of human rights standards to KFOR activities in Kosovo based on relevant states' extraterritorial conduct (Cerone 2001; Knoll 2006; Stahn 2001). In international law, it is hard to identify a clear rule that provides for invoking the extraterritorial criteria. Also, there are no clear legal provisions for defining the state's human rights obligations when it acts abroad on its own initiative or as a peacekeeping force under the UN umbrella. In discussing the discomfort of the "powers of international technocrats", Hafner points out that "international organizations could be used by the states as a device to avoid responsibility and accountability by transferring the decision-making competencies to the organization and question the extent of international organizations being bound by the rule of law" (Hafner 2005: 36 ). 
The notion of 'applicability' of human rights standards over international military troops is to a certain extent codified and interpreted by international supervisory mechanisms. However, the issue of "effective implementation of the human rights standards and supervision by an international supervisory mechanism remains very incoherent in the absence of a coherent analytical framework" (Cerone 2006). All major human rights treaties to which NATO member states are parties require states not only to secure but also to establish mechanisms for human rights protection of individuals within their territory and subject to their jurisdiction. The UN Human Rights Committee has consistently held that "a state's jurisdiction extends beyond territorial boundaries interpreting the scope of Article 2(1)" and that it "does not imply that the State party concerned cannot be held accountable for violations of rights under the Covenant which its agents commit upon the territory of another State, whether the acquiescence of the Government of that State or in opposition to it" (Burgos/Delia Saldias de Lopez v. Uruguay 1981). Also, in its General Comment No. 3.1, the UN Human Rights Committee stated that "a State party must respect and ensure the rights laid down in the [1966 UN] Covenant [on Civil and Political Rights] to anyone within the power of effective control of that State Party, even if not situated within the territory of the State Party" (United Nations Human Rights Committee 2004). Furthermore, the Human Rights Committee affirmed that "enjoyment of the Covenant Rights is not necessarily limited to citizens of State parties but must also be available to all individuals, regardless of nationality or statelessness, such as asylum seekers, refugees, migrant workers and other persons who may find themselves in the territory or subject to the jurisdiction of the state Party." The Human Rights Committee affirmed that "this principle also covers the subjects of the State Party that exercise power or effective control while acting outside its territory, despite circumstances in which such power and effective control is established, such as forces constituting a national contingent of a state Party assigned to an international peace-keeping or peace enforcement operation" (United Nations Human Rights Committee 2004). Application of the rights contained in ICCPR in the contexts of military occupation has been confirmed also by the International Court of Justice (ICJ). In its Advisory Opinion in 2004 on Legal Consequences on the Construction of a Wall in the Occupied Palestinian Territory, the ICJ established that "the ICCPR, the International Covenant on Economic Social and Cultural Rights (ICESCR), and the Convention on the Rights of the Child (CRC) applied to the conduct of the Israeli forces in the 
Occupied Territories" (International Court of Justice 2004: paras. 100-109). However, in this opinion the ICJ narrowed application of the ICCPR to the "acts done [...] in the exercise of its jurisdiction by the occupation forces" (International Court of Justice 2004: paras. 109-111).

The European Convention, in its Article 1, provides that a state is "responsible for securing the enjoyment of the rights contained in the ECHR for everyone within that state's jurisdiction" (Council of Europe 1950: Article 1). The case law of the European Court for Human Rights has interpreted 'state jurisdiction' through different standards when assessing whether individuals alleging human rights violations actually fell within the state jurisdiction. The concept of state jurisdiction has been interpreted by the European Court to include cases where representatives of a state have exercised effective control (Cyprus v. Turkey 2001). Also, it may include activities of state agents in territories outside the normal borders of a state party (Abdullah Öcalan v. Turkey 2005) or/and when state representatives are operating internationally (Bankovic v. Belgium 2001). As such, in order for an individual to enjoy the human rights protections that the Convention guarantees, "a victim of a violation must be found to have been at the relevant time within the jurisdiction of the State Party" allegedly violating his or her rights (Al-Skeini and Others $v$. Secretary of State for Defence 2007). This is a very high standard to meet considering the authorization of current and past peace-keeping international missions, their troop deployment and their operation on the ground. The composition of the peace-keeping forces — the civilian or military forces — is usually multinational, operating jointly (joint operation is provided at least in the legal documents establishing them); their operation on the ground is also linked with the national rules of engagement (ROE). Often territories where they operate are not legally defined (i.e. refugee camps, territories between borders) which render the peace-keeping forces' (in) actions unaccountable.

\section{Behrami v. France and Saramati v. France, Germany and Norway}

The two cases Behrami v. France and Saramati v. France, Germany and Norway brought by two Kosovars to the European Court have drawn widereaching attention to the laws of international responsibility and to the 
issue of delegation of powers and attribution of conduct over states when they act jointly in peace-keeping missions. Due to the lack of jurisdiction of national courts based on KFOR privileges and immunities (UNMIK Reg. 2000/47 2000), the two cases were directed to the European Court in 2000. The two applicants complained about the "failure of the troop contributing states to act in accordance with the human rights standards contained in the European Convention" (Saramati v. France, Germany and Norway 2007). On 15 November 2006, the Grand Chamber jointly heard the two applications, even though the two cases dealt with different alleged violations arising from different KFOR responsibilities. The applicant - the father of the victims - in Behrami v. France was complaining about the violation of the right to life (Article 2 of the ECHR) due to the death of his twelve-year son and injury of his other ten-year son by the undetonated cluster bombs dropped during the NATO air campaign. The incident took place in the Mitrovica region, which was under KFOR multinational brigades under French authority. It is relevant here to mention that NATO divided KFOR into four multinational brigades (MNB): France, Germany, USA and United Kingdom brigades, each responsible for ensuring the security of a specific region of Kosovo. In Saramati v. France, Germany and Norway the applicant, Mr. Saramati, challenged the legality of his detention under COMKFOR Directive 42, basing his application on violation of the right to liberty and security (Article 5 ECHR). Mr. Saramati was also complaining that he had no effective remedy available against KFOR (Article 13 ECHR), and that his right to a fair trial had been violated (Article 6, para. 1 ECHR). In Behrami v. France, the applicant argued that the only authority in the region of Mitrovica mandated to secure the safety of the inhabitants, who were actually refugees returning after the 1999 conflict, were French troops. Despite notification by the local inhabitants about the existence of cluster bombs, the French KFOR took no steps to remove them; they did not notify the local inhabitants on the dangers of the cluster bombs, or fence off or mark the area (Behrami v. France 2007, para. 6).

In the case of Saramati v. France, German, and Norway, the applicant was one of many Kosovars detained on the order of the KFOR Commanders (first Norwegian and then French). It is to be noted here that the applicant latter withdrew the complaint against Germany. He was held for six months without any legal basis or judicial oversight (Saramati v. France, Germany and Norway 2007). Mr. Saramati was a Commander of a Kosovo Protection 
Corps Brigade operating under UNMIK police authority. He was held in detention based on grounded allegations of committing criminal acts from 17 September 2001 to 23 January 2002, although the Supreme Court of Kosovo had ordered his release in June 2001. In the Behrami case, the French authorities submitted their rebuttal, arguing that KFOR was an international structure established under and only responsible to the United Nations (Behrami v. France 2007: para. 68): as such, it was the UN and not France that had effective authority over the territory of Kosovo. French authorities also submitted that the case did not fall within the jurisdiction of Article 1 of the ECHR since the incident did not occur in the territory of France (ibid.: para. 67). In the case of Saramati v. France, Germany and Norway, the three governments and the UN provided comments. Six other European countries provided their standing to the European Court opposing the application of the European Convention standards to military operations out of the country (Behrami v. France 2007; Saramati v. France, Germany and Norway 2007: paras. 91-120).

\section{The reasoning of the European Court on Behrami v. France and Saramati v. France, Germany and Norway}

Since its foundation, the European Court has succeeded in establishing itself as a leader in international mechanisms for human rights protection. Through its case law, the European Court guides states in the protection and promotion of individuals' rights, and through its reasoning and interpretations has enhanced and reshaped international human rights law. The applications in Behrami v. France and Saramati v. France, Germany and Norway provided the Court with a unique opportunity to further contribute to the already much debated issue of the accountability of international organizations and their troop-contributing states (United Nations International Law Commission 2004; United Nations International Law Commission 2011). However, the reasoning of the Court on the admissibility decision of both cases came as a surprise to the legal community in Kosovo, to international scholars and above all to the citizens of Kosovo. Contrary to its previous interpretations of "territorial jurisdiction" (ECHR Article 1), and "effective control" (Loizidou v. Turkey 1995), the Court focused on analysing its jurisdictional ratione personae over the cases. Here the Court undertook to "review the acts of the respondent States carried out on behalf of the UN and, more generally, as to the 
relationship between the Convention and the UN acting under Chapter VII of its Charter" (Behrami v. France and Saramati v. France, Germany and Norway 2007: para. 146). In doing so, the Court also considered the mandate and legality of the delegation of powers between the two international presences, UNMIK and KFOR. In analysing "whether the actions and inactions undertaken by KFOR can be attributed to troop contributing states", the European Court "decided by majority that those (in)actions derive from UN SR 1244 and with it are attributable to the UN and not to members states comprising KFOR" (ibid.: paras. 140-141). UNMIK was authorized by the UNSC based on Chapter VII powers and it did delegate powers to the KFOR.

From here, the Court turned to determine the legality of the delegation of powers from UNMIK to KFOR. The Court analysed in detail the UNMIK chain of command based on its constituent documents and stated that "The UNSC was to retain ultimate authority and control over the security mission and it delegated to NATO, in consultation with non-NATO member states, the power to establish and maintain operational command of KFOR" (ibid.: para. 129). The Court maintained that "even though the troopcontributing nations had some authority over their troops (for reasons, inter alia, of safety, discipline and accountability) and certain obligations in their regard (for example, material provision), the SC retained ultimate authority and control and [...] effective command of the relevant operation matters was retained by NATO" (ibid. 2007: paras. 138-140). This Court's reasoning might sound convincing in light of the SC political decision establishing an UN-mandated security force for Kosovo as "an equal international presence" with UNMIK, but NATO-led and de facto NATO-commanded operations involved no strategic direction from any UN body. Moreover, the MTA that allowed KFOR establishment was signed before UN SCR 1244, and SC authorities over KFOR were only limited to the regular reports by the officials of the international presence to the UNSC.

In its further analyses of the responsibilities of UNMIK and KFOR, the Court found that "issuing detention orders fell within the security mandate of KFOR and that the supervision of de-mining fell within UNMIK's mandate" (ibid.: paras. 122-126). In so doing, with respect to the Behrami case, the Court found that it was "KFOR's failure to secure the site [where the detonation had taken place] and provide information thereon to UNMIK" 
(ibid.: para. 126). Despite KFORs responsibility in relation to demining, KFOR was not acting independently in this task; KFOR undertook this task on behalf of UNMIK. As sUch, UNMIK was mandated with demining tasks and KFOR's inaction was attributable to the UN (ibid.: para. 163). The Court firmly stated that "given that UNMIK was a subsidiary organ of the United Nations and that KFOR was exercising powers lawfully delegated under Chapter VII, their actions were directly attributable to the UN, an organization of universal jurisdiction fulfilling its imperative collective security objective" (ibid.: para. 151). The Court concluded that "in these circumstances, the applicants' complaints were incompatible ratione personae with the provisions of the Convention and declared both applications inadmissible" (ibid.: para.152).

From the above discussion, it is evident that the European Court's holding that human rights violations resulting from KFOR's (in)actions were attributable to the UN and not to the troop contributing states deviated from its own developed standards for attribution of wrongful acts. Considering the circumstances of the case, in particular in Behrami $v$. France, if the 'effective control' test and territorial jurisdiction had been applied as established in its case law, the Court would have come to the finding that the failure to demine in the Mitrovica region (detention in Saramati) would be attributable to France (Germany and Norway). Similarly, if the delegation of the tasks by UNMIK to KFOR combined with the 'effective control' test had been considered by the Court, KFOR's (in)actions could have been qualified with dual or multiple attribution to NATO, the UN and France. Certainly, the reasoning of the Court when rejecting the applications on admissibility grounds negatively impacted the overall complex human rights situation in Kosovo (European Commission for Democracy through Law 2004). By concentrating in its analyses on ultimate authority and the control test, the legality of transfer of powers and responsibilities from UNMIK to KFOR - through interpreting UN SC Resolution 1244 and the UN Charter - the Court limited the possibilities for redress of individuals under international peace-keeping authorities. 


\section{Conclusion}

The measures undertaken by KFOR to implement its mandate and authority as provided in UN SCR 1244 had adverse effects on nearly all of the rights guaranteed in international human rights law and applicable in Kosovo. NATO policy and state intervention in its troops' command and control caused an inconsistency in operations which resulted in a failure to protect human rights in Kosovo, in particular during KFOR operations to ensure security and quash interethnic violence. Infringement of individual rights through COMCFOR detention not only affected the individual's right to liberty and security of the person, but also affected the enjoyment of the right to a remedy and the right to compensation when the defendant was found not guilty. KFOR activities, due to its military strategy and operational level, were covered by broader immunities and privileges that practically rendered KFOR unaccountable for its actions. KFOR was not operating in a legal vacuum; however, the nonexistence of a specific legal framework that provided for the application of human rights standards to specific actions of KFOR made Kosovars consider the general principles of international law, mainly the extraterritorial application of human rights standards. However, the reasoning of the Court on the admissibility decision on Behrami v. France and Saramati v. France, Germany and Norway showed that the court relied on the formal hierarchy concerning the establishment of KFOR to escape an unfriendly precedent for future peacekeeping actions; otherwise, in the future, countries would hesitate to contribute their troops to international security operations. These two decisions showed again that peace-keeping is an essentially political institution and confirmed that Kosovars' right to an effective remedy was compromised when KFOR failed to protect human rights in Kosovo.

It is the standing of this paper that the conflicting issues related to the legal bases that establish the international peacekeeping structures and the internal operational rules of the troop-contributing forces need to be reconsidered. The legal bases for establishing future international security forces in international administrations need to allow for the establishment of a (non-)judicial mechanism as an integral part of the mission with the jurisdiction to handle human rights violations alleged by the inhabitants under their authority and provide for a reparation modality mechanism in order to respect the right to be compensated. 


\section{B Bibliography}

Abdullah Öcalan v. Turkey, 2005. Application no. 46221/99 (ECtHR, 12 May 2005).

Behrami v. France, 2007. Agim Behrami and Bekir Behrami v. France. Application no. 71412/01 (ECHHR, 2 May 2007).

Al-Skeini and Others (Respondents) v. Secretary of State for Defence (Appellant). Al-Skeini and Others (Appellants) v. Secretary of State for Defence (Respondent) (Consolidated Appeals), 2007. UKHL 26, United Kingdom: House of Lords (Judicial Committee), 13 June [online]. Available at: http://www.refworld.org/cases,GBR_ HL,4672880a2.html (Accessed 1 September 2017).

Amnesty International, 2000. Federal Republic of Yugoslavia (Kosovo): setting the standard? UNMIK and KFOR's response to the violence in Mitrovica. [pdf]. Available at: https://www.amnesty.org/ download/Documents/140000/eur700132000en.pdf (Accessed 23 August 2017).

Amnesty International, 2004a. Kosovo and Bosnia-Herzegovina: the apparent lack of accountability of international peacekeeping forces in Kosovo and Bosnia-Herzegovina. 21 March [online]. Available at: https://www.amnesty.org/en/documents/ eur05/002/2004/en/ (Accessed 25 June 2017).

Amnesty International, 2004b. Serbia and Montenegro (Kosovo/Kosova): The March violence: KFOR and UNMIK's failure to protect the right of the minority communities. [online]. Available at: https://www. amnesty.org/en/search/ (Accessed 5 July 2017).

Banković and others v. Belgium, 2007. Application no. 52207/99 (ECtHR, 19 December 2007).

Benedek, W., 2005. Final status of Kosovo: the role of human rights and minority rights. Chicago-Kent Law Review, 80(1): 215-233

Burgos/Delia Saldias de Lopez v. Uruguay, 29 July 1981. Communication No.52/1979, UN Doc. CCPR/C/OP1. 
Cerone, J., 2001. Minding the Gap: Outlining KFOR Accountability in Postconflict Kosovo. European Journal of International Law, 12(3): 469-488.

Cerone, J., 2002. Outlining KFOR Accountability in Post-Conflict Kosovo. American Society for International Law, 5(15), [online]. Available at: https://www.asil.org/insights/volume/5/issue/15/outlining-kforaccountability-post-conflict-kosovo (Accessed 28 September 2017).

Cerone, J., 2006. Out of bounds? Considering the reach of international human rights law. Centre for Human Rights and Global Justice Working Paper 5, [pdf]. Available at: http://chrgj.org/wp-content/ uploads/2012/07/WPS_NYU_CHRGJ_Cerone_Final.pdf (Accessed 28 June 2017).

Clapham, A., 2006. Human rights obligations of non-state actors. Oxford: Oxford University Press.

CNN, 1999. G-8 countries endorse Kosovo plan. [online]. Available at: http://edition.cnn.com/WORLD/europe/9905/06/kosovo.05/index. htmleiref=storysearch (Accessed 25 June 2017).

Committee on Legal Affairs and Human Rights, 2001. Lawless areas within the territory of Council of Europe Member States (Doc.8993, 8 March 2001). Rapporteur: Mr Pourgourdes, [online]. Available at: https://assembly.coe.int/nw/Xml/XRef/X2H-Xref-ViewHTML.asp? File $\mathrm{ID}=9212$ \&lang=EN (Accessed 23 August 2017).

Council of Europe, 2002. Office of the Commissioner for Human Rights, Kosovo: the human rights situation and the fate of persons displaced from their homes. Report by Mr. Alvaro Gil-Robles, Commissioner for Human Rights, Strasbourg, 16 October 2002 [pdf]. Available at: http:// www.refworld.org/pdfid/415971228.pdf (Accessed 5 July 2017).

Council of Europe, 1950. European Convention for the Protection of Human Rights and Fundamental Freedoms, as amended by Protocols Nos. 11 and 14, Strasbourg, 4 November 1950, ETS 5 [online]. Available at: http://www.refworld.org/docid/3ae6b3b04.html (Accessed 3 October 2017).

Cyprus v. Turkey, 2001. Application no. 25781/94, (ECHHR, 10 May 2001). Delia Saldias de Lopez v. Uruguay, 1981. CCPR/C/13/D/52/1979 (United 
Nations Human Rights Committee).

De Wet, E., 2004. Chapter VII powers of the United Nations Security Council. Oxford: Oxford Hart Press.

Direk, F. O., 2015. Security detention in international territorial administrations: Kosovo, East Timor and Iraq. Leiden: Boston, Brill Njihoff.

Eccles, E. H., 1965. Military concepts and philosophy. New Brunswick, NJ: Rutgers University Press.

European Commission for Democracy through Law, 2004. The human rights situation in Kosovo. Background information and issues for discussion. Strasbourg, 4 June 2004. Opinion no. 280/2004.

European Parliament DG Information, 2001. The library Subject Team on Foreign Affairs. COMCFOR Directive 42, 9 October [pdf]. Available at: http://www.statewatch.org/ cia/documents/LibraryCOMKFOR-2004-006.pdf (Accessed 5 July 2017).

Hafner, G., 2005. The rule of law and international organizations. Berlin: Duncker \& Haubalt.

Human Rights Watch, 2004. Failure to protect anti-minority violence in Kosovo. March 2004, [online]. Available at: https://www.hrw.org/ report/2004/07/25/failure-protect/anti-minority-violence-kosovomarch-2004 (Accessed 5 July 2017).

International Court of Justice, 1949. Reparation for injuries suffered in the service of the United Nations. Advisory Opinion, 1949 I.C.HJ. 174.

International Court of Justice, 2004. Advisory opinion concerning legal consequences of the construction of a wall in the occupied Palestinian territory. [online]. Available at: http://www.icj-cij.org/ en/case/131 (Accessed 25 August 2017).

International Crisis Group, 2004. Collapse in Kosovo. Europe Report No. 155, 22 April [pdf]. Available at: https://www.files.ethz.ch/isn/28082/155_ collapse_in_kosovo_revised.pdf (Accessed 5 July 2017).

International Law Commission, 2011. Draft articles on the responsibility of international organizations, [pdf]. Available at: http://legal. un.org/ilc/texts/instruments/english/draft_articles/9_11_2011.pdf 
(Accessed 23 August 2017).

Joseph, P. E., 2003. Macedonia: the risks of complacency. Meeting Report 277, 2003.

Knoll, B., 2006. Beyond the mission civilisatrice: the properties of a normative order within an internationalized territory. Leiden Journal of International Law, 19(2): 275-304.

Kouchner, B., 2001. A first-hand perspective from Kosovo. In: Spillmann, R. K., Bernaver, T., Gabriel, J. M. and Wenger, A. eds. Peace support operations: lessons learned and future perspectives. Bern, Berlin, Bruxelles, Frankfurt/M., New York, Oxford, Wien: Peter Lang. pp. 137-145.

Marshall, D. and Inglis, S., 2003. Human rights in transition: the disempowerment of human rights-based justice in the United Nations mission in Kosovo. Harvard Human Rights Journal, 16(95): 95-146.

Military Technical Agreement, 1999. Military technical agreement between the international security force (KFOR) and the governments of the Federal Republic of Yugoslavia and the Republic of Serbia. 9 June [online]. Available at: http://www.nato.int/kosovo/docu/ a990609a.htm (Accessed 5 July 2017).

Murphy, R., 2005. UN peacekeeping in Lebanon, Somalia and Kosovo. Cambridge: Cambridge University Press.

Organization for Security and Cooperation in Europe, 2002. Department of Human Rights and Rule of Law Legal System Monitoring Section, 2001-2002, 24 January 2002 [online]. Available at: http://www. osce.org/kosovo/documents.html (Accessed 25 June 2017).

Reinhardt, K., 2001. Lessons learned as commander KFOR in Kosovo. In: Spillmann, R. K., Bernaver, T., Gabriel, J.M. and Wenger, A. eds. Peace support operations: lessons learned and future perspectives. Bern, Berlin, Bruxelles, Frankfurt/M., New York, Oxford, Wien: Peter Lang. pp. 147-154.

Saramati v. France, Germany and Norway, 2007. Application no. 78166/01 (ECHHR, 2 May 2007). 
Serbia and Montenegro v. France, 2004. Aplication no. 29-4-1999 (International Court of Justice).

Spillmann, R. K, Bernaver, T., Gabriel, J., Wenger, A. eds., 2001. Peace Support Operations: Lessons Learned and Future Perspectives. Bern, Berlin, Bruxelles, Frankfurt/M., New York, Oxford, Wien: Peter Lang.

Stahn, C., 2001. The United Nations transitional administrations in Kosovo and East Timor: a first analysis. In: Max Planck Y.B. of UN Law, (2001) 105.

Titina Loizidou v. Turkey, 1995. Application no. 15318/89 (ECHHR, 23 March 1995).

United Nations International Law Commission 2004. Special Rapporteur, Second report on responsibility of international organizations. A/ CN.4/541. (2 April 2004).

United Nations International Law Commission, 2005. Report of the International Law Commission (ILC), fifty-seventh session. Commentary (2) on draft Article 13 on the responsibility of international organizations. 2 May- 3 June and 11 July-5 August 2005. UN Doc. A/CN.4.

United Nations Secretary General's Report on the United Nations' Interim Administration Mission in Kosovo, 1999. UN Doc. S/1999/779.

United Nations Department of Peacekeeping Operations, 2008. United Nations peacekeeping operations: principles and guidelines 68 (Capstone Doctrine). [pdf]. Available at: http://www.un.org/en/ peacekeeping/documents/capstone_eng.pdf (Accessed 25 June 2017).

United Nations Department of Peacekeeping Operations, 2008. Department of Field Support, Policy on Authority, Command and Control in United Nations Peacekeeping Operations, Ref. 2008.4, Feb. 2008.

United Nations Human Rights Committee, 2004. General comment No.3 1(80): nature of the general legal obligation imposed on state parties to the Covenant 26/05/2004. CCPR/C/21Rev.1/Add.13 (General Comments). 
United Nations Security Council Resolution 1244, 10 June 1999.

United Nations Security Council Peace Plan, 1999. Agreement on the principles to move towards a resolution of the Kosovo crisis presented to the leadership of the Federal Republic of Yugoslavia by the President of Finland, Martti Ahtisaari, representing the European Union, and Viktor Chernomyrdin, Special Representative of the President of the Russian Federation, 3 June 1999. UN Doc. S/1999/649.

United Nations Security Council, 2008. Report of the Secretary-General on the United Nations Interim Administration Mission in Kosovo, 28 March 2008. UN Doc. S/2008/211

UNMIK Reg. 1999/24. Regulation no.1999/24 on the law applicable in Kosovo. 12 December 1999.

UNMIK Reg. 2000/47. Regulation No. 2000/47 on the status, privileges and immunities of KFOR and UNMIK Personnel in Kosovo. 18 August 2000.

UNMIK Reg. 2000/59. Regulation no.2000/59, amending UNMIK Regulation no. 1999/24 on the law applicable in Kosovo. 27 October 2000.

UNMIK Reg. 2001/7. Regulation no. 2001/7 on the authorization of possession of weapons in Kosovo. 21 February 2001.

Youngs, T., Oakes, M., Bowers, P. and Hillyard, M., 1999. Kosovo: Operation Allied Force. Compiled for Members of Parliament (London, UK: House of Commons Library, 29 April 1999), Research Paper 99/48, [pdf]. Available at: http://researchbriefings.files.parliament.uk/ documents/RP99-48/RP99-48.pdf (Accessed 23 August 2017).

Zwanenburg, M., 2005. Accountability of peace support operations. Leiden and Boston: Martinus Nijhoff Publishers. 
Remzije Istrefi (remzie.istrefi@uni-pr.edu) works as Professor at the Faculty of Law, University of Prishtina. She was a postdoc fellow at the Institute for International Relations of the University of Graz, Austria (sponsored by Higher Kos). Ms. Istrefi holds a PhD with a specialization in International Human Rights Law and International Organizations. She finished her studies in International Human Rights Law (L.L.M) at the University of Notre Dame, Indiana, USA (Ron Brown Fellow) after receiving her BA at the Faculty of Law at the University of Prishtina. In 2008, Ms. Istrefi was awarded the Fulbright Exchange Scholar Program at the John Hope Franklin Centre for Multidisciplinary Studies at Duke University, NC. Ms. Istrefi is a member of the bar exam evaluation commission in Kosovo and is also actively involved as a researcher in various research projects. Ms. Istrefi has published several scientific articles in the field of human rights and has contributed to numerous books published in Europe. 